\title{
PHYTOTECHNOLOGY APPLIED TO MUNICIPAL WASTEWATER TREATMENT ON IRRIGATED FIELDS OF GDANSK (POLAND) (1872-1992)
}

\author{
Piotr Kowalik \\ Ziemowit Suligowski \\ Gdansk University of Technology, Poland
}

\begin{abstract}
By 1863 the population of Gdansk was about 100000 people and the water consumption was predicted on the level of 100 litres per person a day, which meant about $10000 \mathrm{~m}^{3} /$ day of wastewater. The water supply and sewerage systems were completed in 1869-1871 and the wastewater treatment plant built in 1872 (it was situated $3 \mathrm{~km}$ from the city). The wastewater treatment plant consisted of the 320 ha of the irrigation fields of Sianki. These fields were never used for agriculture. Sand dunes were levelled and ditches were constructed on 2 levels. Ditches on the upper level received wastewater, while those at the lower level served to drain treated wastewater. From the upper ditches wastewater was distributed to flood and irrigate sandy soils covered by grass. The hydraulic load was above $3000 \mathrm{~mm}$ per year in 1872 , increasing year after year and ending with $8000 \mathrm{~mm}$ per year in 1972. Efficiency of pollution removal was $80 \%$. The irrigation fields on sandy dunes served well until the 1970 s, when the plant was overloaded, neglected and included into the industrial area of harbour. Fields were covered by grass monoculture for hay production of couch-grass (Agrophyrum repens). In the locations of local sedimentation of sewage sludge the monoculture of nettle (Urtica) was developed. Due to the poor management, more and more wastewater was flowing on the surface of the fields, instead of infiltrating and percolating through the sandy soil, which reduced their purification efficiency from 80 to $10 \%$. During the period of 1992-1994 the plant was closed after 120 years of continuous use.
\end{abstract}

\section{KEYWORDS}

Phytotechnology, wastewater, irrigation fields, sandy soils, wetlands.

\section{INTRODUCTION}

Phytotechnologies are defined by UNEP (see: //www.unep.or.jp/letc/) as "the application of science and engineering to study problems and provide solutions involving plants." This term is useful in promoting a broader understanding of the importance of plants and their beneficial role within both societal and natural systems. Underlying this concept is the use of plants as living technologies to help address environmental challenges. According to UNEP definition "phytotechnology applications employ ecological engineering principles and are considered to be ecotechnologies. Hence phytotechnologies are based on the science of ecology and consider the ecosystem as an integral component of human and societal interventions involving the natural environment." 
Several examples of phytotechnologies can be mentioned. In the Netherlands this technology was used for reclamation of soils dewatered from the bottom of lakes and sea. In Israel this ecotechnology is applied for development of forest on the previously desert soils. In Sweden where the agricultural fields were changed into energy forestry plantations, the phytotechnology is used to produce fired wood.

In this paper we are describing the use of plants and soils for wastewater treatment on wetlands, on previously sandy dunes. The terrestrial ecosystems and plants were used to solve pollution problem that otherwise would be more harmful to aquatic or maritime ecosystems of Baltic Sea.

The idea of irrigation of soils by wastewater and treatment of this wastewater in soil was created in XIX century, mainly following the ideas of Edwin Chadwick (1800-1890) in England. He introduced so called "sanitary ideas" of public health engineering and sanitary engineering. He was a social reformer who devoted his life to sanitary reform in Britain. His ideas culminated in the "Report ... on Enquiry into Sanitary Conditions of the Laboring Population of Great Britain" which he published privately and at his own expense in 1842. In 1847 he headed the parliamentary commission and issued the report advocating separation of sewage and drainage systems. He advocated a "separate system" plan which involved the removal of storm water in separate storm drains and the removal of sewage by separate house drains and sewers. These ideas were approved by the British government and were carried out by the engineers in many countries, including Germany. This environmental and sanitary thinking allowed the development of sanitary systems (from transportation systems to preventive treatment).

E. Chadwick advocated the clean water intake for water supply away from the city and dumping of wastewater far from the city. This was confirmed with microbiological arguments, when in 1857 the ideas of Pasteur were published. After 1860 in Europe started the environmental sanitation, however not to solve the problem of wastewater treatment but just to move pollution away from the town, in centralized and very costly solutions.

\section{BEGINNING OF THE INFRASTRUCTURE}

Solutions in Gdansk can be an example of solving sanitary problems using phytotechnology in the middle of XIX century. By 1863 the population of Gdansk was about 100000 people and the water consumption was predicted on the level of 100 litres per person a day, which meant about $10000 \mathrm{~m}^{3} /$ day of wastewater. The situation of the sanitary infrastructure was described in the earlier paper and it is recalled partly here [6]. The mayor of the town L. von Winter decided to construct a new water supply and sewerage systems [1]. The main designer of the new sanitary system was E. Wiebe, a railway engineer. His main consultant was B. Latham, a sanitary engineer and president of the London Society of Engineers.

After a study tour to England and Western Europe they made, together with a group of planners, a feasibility study that was published in the form of a book in 2 volumes in 1865 [13]. Their plan was accepted by the city council. The new water source was a groundwater located in the gravel formations of the village of Pregowo, about $15 \mathrm{~km}$ from the city, $110 \mathrm{~m}$ above sea level (a.s.l.). This location was chosen in order to avoid possible contamination. A water reservoir was constructed $43 \mathrm{~m}$ a.s.l. in Orunia. The city itself is located $2-4 \mathrm{~m}$ a.s.l. The aqueduct was a cast iron pipeline with a diameter of $418 \mathrm{~mm}$. It was dug underground and was $14 \mathrm{~km}$ long. This main water pipe is still functioning today without any major problems in capacity. The water distribution pipelines in the city were constructed during 1869-1871 to supply water to 100000 inhabitants.

Meanwhile the sewerage system was completed and the streets were paved by stones imported from Sweden. The sewers were laid along the streets in a relatively shallow fashion 
in order to avoid contact with the groundwater. The main collectors ended in the Old Motlawa and New Motlawa Rivers in the harbour. Siphons were installed under the river beds to conduct the wastewater by gravity to the small Olowianka Island, located about $1 \mathrm{~m}$ a.s.l. The main pumping station was completed on this island and a $3 \mathrm{~km}$-ling pressure pipe led to the wastewater treatment plants [9]. Its pumping station has worked to the present without major changes.

The first wastewater-treatment plant consisted of the irrigation fields of Sianki (in German: Heubude). The sewerage systems were completed in 1869-1871 and the wastewater treatment plant was constructed in $1872,3 \mathrm{~km}$ from the city. This consisted of the 180-320 ha of the irrigation fields. These fields were never used for agriculture and have always served as a phytotechnological treatment plant.

\section{CONSTRUCTIONS}

Sand dunes were levelled and ditches were constructed on 2 levels. Ditches on the upper level received wastewater, those at the lower level served to drain treated wastewater. From the upper ditches wastewater was distributed to flood and irrigate sandy soils covered by grass (Figure 1, Figure 2).

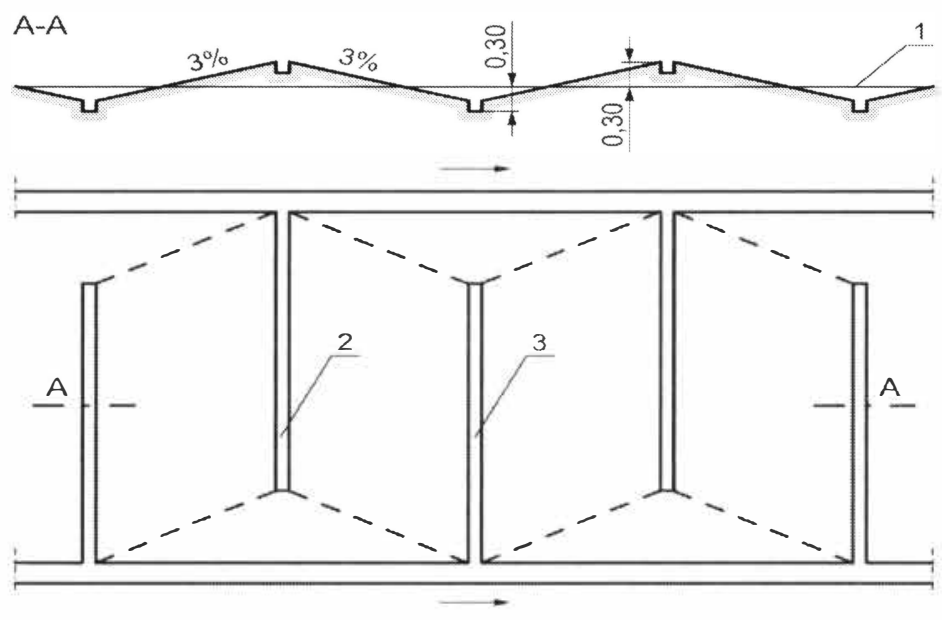

Figure 1. Irrigation system with flood of the fields on the artificial slopes. 1-Original level of the ground; 2 - ditch for irrigation by wastewater; 3 - ditch for drainage of treated wastewater (a fter [15]). 


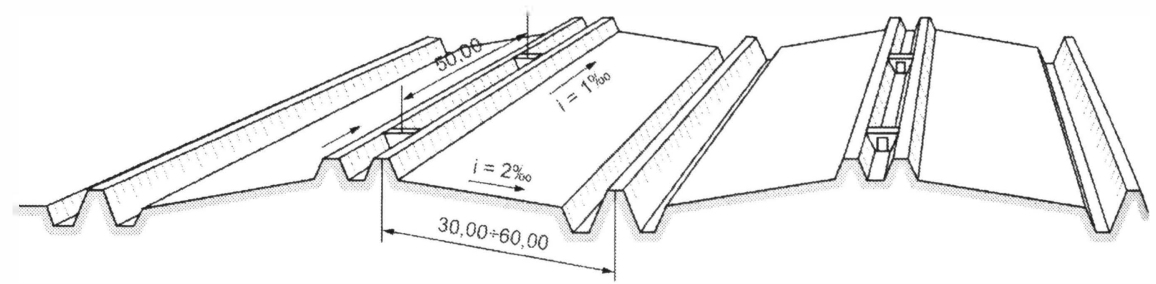

Figure 2. System of irrigation and drainage of the fields in Gdansk-Sianki

Originally, the plant consisted of 160-180 ha of dunes. After treatment, wastewater was dumped into the Vistula River close to the Baltic Sea. In 1908, the fields were extended up to 320 ha. The amount of wastewater was above $3000 \mathrm{~mm}$ per year in 1872, increasing year after year and ending with $8000 \mathrm{~mm}$ per year in 1972. Rainfall in this area is $600 \mathrm{~mm}$ per year. Efficiency of pollution removal was $80 \%$ at the end of XIX century. It was reported that the wastewater plant was eliminating nearly all ammonia and phosphorus from wastewater. According to $[2,3]$ and [10] the average results were as follows: in summer phosphorus removal was $100 \%$ and ammonia removal $82 \%$, in winter the figures were $95 \%$ and $42 \%$, respectively. The sand dunes were rich in iron, which was the reason for the high degree of nutrient removal.

Finished in 1872, this sanitary system was the first comprehensive water supply and sewerage system on the European continent. It consisted of a groundwater intake, distribution lines, and a sewer system in the city, a central pumping station, a wastewater-treatment plant, and dumping of wastewater after treatment into the river under monitoring.

After 1872, many suburban areas were divided into small districts, and many new houses were constructed. This activity resulted in an increase in the population of Gdansk to 120000 by 1880 and 170000 by 1910 .

The irrigation fields on sandy dunes served well until the 1970s, when the plant was overloaded, neglected and included to the industrial area of harbour. Due to poor management, more and more wastewater was flowing on the surface of the fields, instead of infiltrating and percolating through the sandy soil, which naturally reduced their purification efficiency from 80 to $10 \%$. In 1994 the plant was closed after 122 years of continuous use.

\section{VEGETATION AND SOILS}

Fields in Gdansk-Sianki were covered by grass monoculture for hay production of couchgrass (Agrophyrum repens) and in the locations of local sedimentation of sewage sludge the monoculture of nettle (Urtica) was developed. Soil profile was greatly changed under the influence of the irrigation by wastewater and under the change of the water conditions of soils. Evolution of soils started from the pure sandy dunes, changing to forest podzols, sod covered podzols with gley formation in subsoil, rich in organic matter shallow boggy black earths and ending with shallow peat soils on the gley sandy subsoil [8]. This evolution of soil profiles was generated by the regulation of water conditions in the fields. 


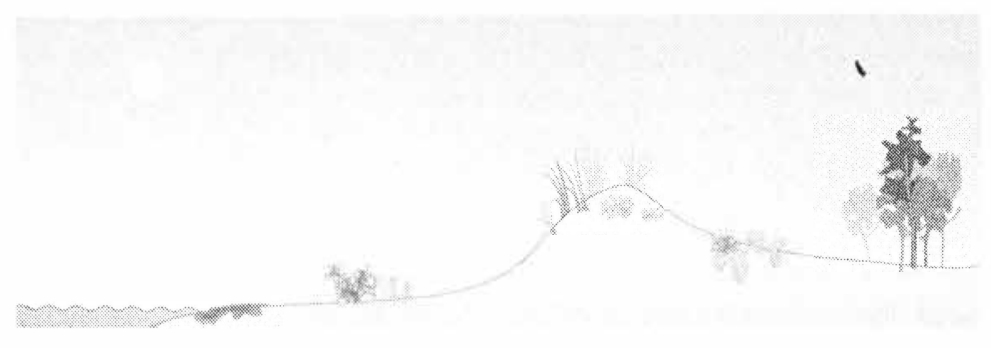

Figure 3. Sandy dunes on the Baltic coast

\subsection{Characteristic of dune soils}

Sandy dunes on the Baltic Sea coast are created by the accumulation of sand carried by the sea waves. The next step is the eolian activity of wind formatting the dunes in one, two or three ridges. These sandy dunes in the region of Gdansk are covered here by vegetation and are stable. Close to the water developed different salt-tolerant grasses, further are sedges (Carex) and willows (Salix caspiniana) and finally there are forest ecosystems with pine (Pinus) trees.

Soils are formed here on the very uniform material of coarse sand, containing mainly one sand fraction of the diameters between 0,1 to $0,5 \mathrm{~mm}$. Sand is located on the different altitude above sea level, with different depth of the groundwater and with different conditions for accumulation of the organic matter on the surface and in the topsoil [8]. Most common are soils containing pure coarse sand, sandy soils rich in water in the local depressions in the dunes, and light rusty podzols under the pine forest. Soils are podzols or pseudo-podzols on the top of the dunes and in the local depressions, where the forest is denser and where the accumulation of organic matter is more distinct. In case of very shallow ground water the process of podzolisation is combined with the formation of boggy soils, giving the podzols with gley subsoil or even the shallow peat soils on the gleyed sand.

Mean depth of the ground water on the sandy dunes is in the range from 80 to $145 \mathrm{~cm}$. Mean rainfall is about $500 \mathrm{~mm}$ per year, in which about $100 \mathrm{~mm}$ is the rainfall during winter, from October till March. The natural vegetation of the dune area is formed in two very different complexes. In case of dry slopes of sandy dunes we can observe dry pine forest. In local depressions between dunes there are wetter conditions and development of fresh forest is possible, with alder (Alnus), willow (Salix) and green undergrown with grass (Aira), mosses and shrubs (Vaccinium vitis idea, Vc. myrtillus and others).

It is clear that if the ground water is closer to the surface than the soil forming processes are more intensive (Stremme [11]). The dune sand forms the soil profiles of podzols, rusty pozols, gley podzols or podzols below the new sand. North and East areas surrounding the irrigated fields are covered by such soils and before irrigation this was the natural environment of dunes.

If the ground water on dune is very deep (below $150 \mathrm{~cm}$ than the soil surface) is very dry and bare, which causes that only lichens (Kladonia) and small grasses are present. Without vegetation covering the soil is dry during longer periods. Organic matter is not produced and consequently it is not cumulated. Development of pine forest does not change much the ecosystem, because most of the plants are not able to grow here, the only exception being pine trees with very deep roots to ground water. 
Topsoil is not protected by the vegetation and thus it is very dry all the summer [11]. Soil profile of these soils is defined as initial stage of podzols under forest (Table l).

On the area of dunes with high ground water level (shallower than $140 \mathrm{~cm}$ ) more and more plants are able to survive, developing deep roots. They are trees and shrubs, producing leaves, needles and litter. Soil became protected against wind erosion and new organic matter is stimulating microbiological activity in the soils. Organic matter may produce humus and thus minerals are weathered, increasing fertility of soil. In the soil profile we can notice $\mathrm{Fe}(\mathrm{OH})_{3}, \mathrm{Al}(\mathrm{OH})_{3}$ and fresh organic matter. Process of podzolization is changing soil profile morphology. Shallow ground water is generating gley process from subsoil, with reduction of chemicals. Gley process is changing colours of many soil components into grey, blue-grey and green-grey colours. As a final result the soil profile is forming gley podzols or simple podzols.

If the ground water is very close to the soil surface, usually in the local depressions between dunes mosses (mainly Sphagnum) develop on the soil. The may create shallow peat layers and peaty soils [11].

\subsection{Dune soils irrigated by wastewater}

Dune soils were utilized for the irrigation of wastewater of the city of Gdansk and wastewater treatment in soil environment. It started during spring 1872. They were the first soils irrigated by wastewater on the European continent (Wierzbicki [14]). After 120 years of irrigation it is possible to observe the evolution of the soil environment here.

During years 1869-71 pine forest was cut, dunes were leveled and ditches for wastewater flow were constructed, as indicated in Figure 1 and Figure 2. At the beginning of 1872 only 180 ha were utilized, but in the next years additional 120 ha were included, ending with 320 ha at the beginning of twenty century [7].

Hydraulic load can be calculated, dividing the amount of wastewater $\left(10000 \mathrm{~m}^{3} /\right.$ day) by the surface area of the fields (360 ha). During 1912 the hydraulic load of the field was 3300 $\mathrm{mm}$ per year [7], during the year $1958-3650 \mathrm{~mm}$ per year [4] and in $19728000 \mathrm{~mm}$ during the year [12]. Most of the wastewater was not treated at all here. Irrigated fields were never drained and dewatered only by the open ditches.

Table 1. Soil profile of rusty pseudo-podzolic sandy soils of dunes in Gdansk-Sianki [5]

\begin{tabular}{lll}
\hline $\begin{array}{l}\text { Soil } \\
\text { horizon }\end{array}$ & $\begin{array}{l}\text { Depth in } \\
\mathrm{cm}\end{array}$ & Soil morphology \\
\hline $\mathrm{A}_{1}\left(\mathrm{~A}_{2}\right)$ & $0-15$ & $\begin{array}{l}\text { Black coarse sand with low content of organic matter, with tendency } \\
\text { to create powdered structure, with sod layer in topsoil up to } 8 \mathrm{~cm}\end{array}$ \\
\hline $\mathrm{B}$ & $15-90$ & $\begin{array}{l}\text { Black and rust coarse sand, lighter colours in deeper parts, ending with } \\
\text { fawn colour in subsoil }\end{array}$ \\
\hline $\mathrm{C}(\mathrm{G})$ & $90-200$ & $\begin{array}{l}\text { Yellow-fawn-white coarse sand, more grey in subsoil, ground water } \\
\text { on the level of } 140 \mathrm{~cm}\end{array}$ \\
\hline
\end{tabular}

On the dune sands after irrigation of wastewater the succession of grass vegetation and formation of sod layer were observed. Instead of forest podzolic soils were created grassland sod soils with shallow gley formation. After intensive irrigation the ecological and hydraulic situation was changed. Formation of grass and sod in topsoil was stimulated by frequent wastewater irrigation and formation of gley subsoil because of anaerobic conditions and lack of oxygen diffusion from the atmosphere. Old process of podzolisation was dominated now 
by the process of sod formation. Vegetation consisted of grass, intensively and frequently irrigated by wastewater. After these irrigations the soil profile was changed and the soil horizons were:

- living sod full of roots;

- sod formation, rich in organic matter, black or dark-grey in wet conditions;

- podzolic horizon, light and acid;

- iluvial horizon with dominant gley process;

- gley horizon, anaerobic, grey, green or blue;

sandy subsoil from the original dunes.

Such soils cover at least $1 / 2$ surface area of the irrigated fields, but only if the drainage ditches are working properly and the altitude is high. They were used as mowing grassland, to produce hay twice a year.

\subsection{Dune soils changes into boggy wetlands}

Wastewater treatment is possible because of the filtration in sand. On the surface of the sand grains are forming the bio-film with microbes, suspensions and colloids. It is a place of the bio-sorption of the pollutants from wastewater. In the bio-film the supply of oxygen trough diffusion from the atmosphere is easy. Organic matter is changed into humus and partly mineralized into chemicals, acting as fertilizers in the soil. Most important is the positive balance of oxygen in the soil, mainly in the $20-30 \mathrm{~cm}$ of topsoil. Deeper soil layers are anaerobic and oxidation is not possible any more.

If the ground water level is close to the surface and soil is very rich in organic matter from wastewater, the oxygen balance is negative. Lack of oxygen is giving shallow gley layer in soil and succession of the hydrophilic plants, natural for wetlands. Instead of natural grasses appear grasses producing tufts and clusters and sedge (Carex) [16]. The domination of wetland conditions occurred on the half of the surface area of the Gdansk soils irrigated by wastewater. Part of the soils was ponded, or changed in the wastewater lagoons with the vegetation of wetlands. The soil profiles were changed into direction of bog areas, like in Table 2.

Table 2. Soil profile of the local wetlands irrigated by wastewater in Gdańsk-Sianki [5]

\begin{tabular}{|c|c|c|}
\hline $\begin{array}{l}\text { Soil } \\
\text { horizon }\end{array}$ & Depth in $\mathrm{cm}$ & Soil morphology \\
\hline $\mathrm{A}_{0}$ & $0-15$ & Black soil rich in organic matter with sod layer \\
\hline AG & $15-25$ & Dark grey coarse sand permanently saturated by water \\
\hline G & $\begin{array}{l}25-100 \text { and } \\
\text { deeper }\end{array}$ & $\begin{array}{l}\text { White-grey coarse sand with cool colours, uniform, deeper with } \\
\text { blue-grey colours, saturated by water from the depth } 10 \mathrm{~cm} \text {. }\end{array}$ \\
\hline
\end{tabular}

\section{CONCLUDING REMARKS}

Evolution of dune soils is indicating that dry conditions and very wet conditions are not good for soil processes and development of vegetation. In the case of soils irrigated by the wastewater from Gdansk it is visible that the soils were overloaded by high hydraulic load of waste. This was the reason for the creation of the conditions of wetlands and the efficiency of the wastewater treatment in this ecosystem was lost. Still the phytotechnological solution was serving here during 120 years and it was a good and efficient example of utilization of soil for protection of Baltic Sea. 


\section{REFERENCES}

[1] Cieslak R., Biernat. C., 1994. Dzieje Gdanska. Fundacja Rewaloryzacji Gdanska, Gdańsk.

[2] Helm, O. 1875. Über die chemische Beschaffenheit der Kanalflassigkeit und des Abfluss Wassers der Danziger Rieselanlagen. Der 48 Naturforscherversammlung, Graz.

[3] Helm, O. 1881. Chemische Analyse des Abwassers der Danziger Riesenfelder. Schrifen der Naturforscherversammlung Gesellschaft in Deutschland., Ad. V.

[4] Jarosz J., 1958. Uzupełnienie inwentaryzacji pól irygacyjnych w Gdańsku. Biuro Projektów Budown. Komunalnego w Gdańsku (maszynopis).

[5] Kowalik P., 1966. Ewolucja gleb wydm nadmorskich zwiazana bezposrednio z regulacja ich stosunkow wodnych na przykladzie gleb nawadnianych sciekami w miejscowosci Gdansk-Sianki. Gospodarka Wodna, 2, 48-51.

[6] Kowalik P. and Suligowski Z., 2001. Comparison of water supply and sewerage in Gdansk (Poland) in three different periods. AMBIO, 30(4-5), 320-323.

[7] König J., Lacour H., 1914. Die Reinigung städtischer Abwässer in Deutschland nach den natürlichen biologischen verfahren. Landw'irtschaftliche Jahrbücher, 47, 478.

[8] Krzyszowski J., 1952. Gleby Żuław i terenów przyległych. Roczniki Gleboznaw'cze, II, 92.

[9] Kutera, J 1988. Rolnicze wykorzystanie scieków. PWRIL. Warszawa.

[10] Salomon, H. 1907. Die stadtische Abwasserbeseirigung in Deutschland. Gustav Fischer Verlag, Jena. vol. 1.

[11] Stremme H. (jun.), 1942. Der Einfluss des Grundwassers auf die Bodenbildung des Heubuder Dünengebites. Beitrage zur Bodenerforschung des Reichsgaues DanzigWestpreussen, 1, 29.

[12] Swinarski M., 1999. The development of wastewater treatment systems in Gdansk in 1871-1998. European Water Mgmt, 2, 69-76.

[13] Wiebe, E., 1865. Die Reinigung und Entwasserung der Stadt Danzig. Berechnungen, Ueberschlage der Bau und Betriebskosten — und ein Atlas mit Planen und Zeichnungen in Folio. Verlag Ernst und Korn, Berlin.

[14] Wierzbicki J., 1962. Działanie wód ściekowych na glebę. Wrocł. Tow. Nauk., Wrocław.

[15] Wóycicki K., 1956. Kanalizacja, BiA, Warszawa.

[16] Ziaja W., 1958. Wpływ intensywności nawodnień wodami rzeki Ner na skład botaniczny łąk. Roczn. Nauk Roln., 72-F-4, 1411. 